\title{
Patients on Opioid Substitution Treatment in the Republic of Macedonia: What Do Treatment Demand Data Tell Us?
}

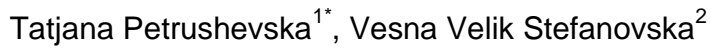 \\ ${ }^{1}$ Ministry of Health of the Republic of Macedonia, Skopje, Republic of Macedonia; ${ }^{2}$ Institute for Epidemiology and Medical \\ Biostatistics, Medical Faculty, Ss. Cyril and Methodius University of Skopje, Skopje, Republic of Macedonia
}

\begin{abstract}
Citation: Petrushevska T, Velik Stefanovska V. Patients on Opioid Substitution Treatment in the Republic of Macedonia: What Do Treatment Demand Data Tell Us? OA Maced J Med Sci.
$2014 \quad$ Jun http://dx.doi.org/10.3889/oamjms.2014.058 Key words: OST; patient demographic characteristics; poly drug use; living status; heroin use; MMT.

"Correspondence: Dr. Tatjana Petrushevska. Ministry of Health, "Vodnjanska" bb, Skopje 1000, Republic of Macedonia. E-Mail: tanja.petrusevska@gmail.com

Received: 27-Feb-2014; Revised: 07-May2014; Accepted: 10-May-2014; Online first: 28-May-2014

Copyright: () 2014 Petrushevska \& Velik Stefanovska. This is an open access article distributed under the terms of the Creative Commons Attribution License, which permits unrestricted use, distribution, and reproduction in any medium, provided the original author and source are credited.

Competing Interests: The authors have declared that no competing interests exist.
\end{abstract}

\begin{abstract}
AIM: The aim of the survey is to analyze national data from opioid substitution treatment (OST) medical records and to compare it with the data from EU countries.

MATERIAL AND METHODS: The survey is quantitative analytical cross-sectional study conducted in the period September - December 2013. Medical records from all patients on OST at national level during the year 2012 were analyzed. EMCDDA questionnaire from treatment protocol 3.0 was used. Data for OST patients on MMT was take from all 12 public treatment facilities, three private centers and 3 prisons. Data for OST patients on buprenorphine was taken from public clinic as the only one responsible for this type of treatment.
\end{abstract}

RESULTS: A comprehensive network, diverse models of treatment intervention exists in the MKD. Total number of OST patients in 2012 in all treatment facilities was 1857 (1356 are in public, 141 in private, 360 in prison settings) $10 \%$ are on Buprenorphine and $90 \%$ are on Methadone, $52 \%$ in age group 20-34. Ratio of male to female heroin clients is $9: 1 ; 162$ are female $(9 \%) ; 107(66 \%)$ are in treatment in the age group 20-34. Average number of OST patients is $0.1 \%$ of the total population in each of the 10 cities analyzed. The mean age at first heroin use is 18 years. $40 \%$ of patients haven't high school. With their family lives $65 \%$ of OST patients; 487 patients (36\%) have children; $80 \%$ of patients use of benzodiazepines.

CONCLUSION: Although treatment network of drug addiction is quite developed, perceived need for further capacity building and increase the quality of medical care implies increasing the availability, diversification in terms of sensitivity to cultural differences, gender, age, ethnicity, as well as the treatment of dependence of different types of psychoactive substances.

\section{Introduction}

The majority of Afghan heroin trafficked into Western and Central Europe comes through the Balkan route. Of the $75-80$ tons of heroin trafficked to Western and Central Europe in 2009, some 60 tons were estimated to have been trafficked from countries of South Eastern Europe (via the Balkan route) [1]. The so-called "Balkan Route" has been used for illicit trafficking since the seventh century as it is the shortest road from the East to Western Europe. The route starts in Afghanistan via Turkey and Macedonia, to Western EU countries as final destination [2]. Narcotics, predominantly heroin, are clear and present danger in Macedonia.

Problem drug use is defined as "injecting drug use or long-duration/regular use of opioids, cocaine and/or amphetamines" [3]. The current number of problem opioid users in Europe can be estimated at about 1.4 million, or $0.41 \%$ of the adult population, with heroin being by far the most widely used opioid [4]. Opiate dependence is a chronic relapsing condition with sometimes catastrophic effects for individuals, families and communities [5]. It is relapsing brain disease characterized by compulsive drug-seeking and use despite harmful consequences and by long-lasting structural and functional changes in the brain [6], which is chronic [7], relapsing [8], progressive, compulsive [9].

Care of IDUs (intravenous drug users) requires interdisciplinary treatment of drug addiction and its psychosocial and somatic complications [10]. There are different treatment modalities available in different countries and studies have shown that treatment interventions can have great benefits. It is 
estimated that approximately one in six problem drug users globally receives treatment for drug use disorders or dependence each year. However, there is a great variation and wide disparity in the availability and accessibility of drug dependance treatment services in different regions [11].

Opioid substitution therapy supplies illicit drug users with a replacement drug, a prescribed medicine such as methadone or buprenorphine, which is usually administered orally in a supervised clinical setting [12]. Substitution treatment contributes to the stabilization of opiate users living situation; it is a longterm intervention with the goal of reducing or eliminating the use of an illicit opioid drug, or to reduce harm and dangers for health, HIV risk behaviors, death from overdose and criminal activity, and financial and other stresses on drug users and their families [13-15]. Conducted a meta-analytic review of cognitive behavioral therapy for drug abuse and dependence including 34 randomized controlled trials (with 2,340 patients treated), larger treatment effect sizes were found for treatment of cannabis, followed by treatments for cocaine, opioids, and, with the smallest effect sizes, poly-substance dependence [16].

Medication-assisted treatment using methadone is one of the most efficacious treatments for opiate addiction [17-18]. Effectiveness of MMT (methadone maintenance treatment) was consistent across culturally diverse settings, between developed and developing countries [19]. Methadone, a complete opioid agonist, approved as a treatment for heroin addiction, can help to reduce heroin use, alleviate withdrawal symptoms, and consequently improve overall health and social relationships. Heroin users taking methadone should be able to improve cognitive functions and return to normal daily activities [20], they can function normally, to overcome their psychological problems and dependence on illicit opiates. Methadone supports them in achieving certain life goals. Dependence on methadone and the drug's paralyzing effects on their emotions were mentioned as common negative consequences [21].

Opioid substitution therapy is not a cure for drug dependence - it is a therapy for management of a chronic condition [22]. Low retention and drug abstinence rates remain a primary problem in treating addiction [23]. Substantial relapse and drop-out rates in MMT cohorts have been observed in various settings, due to multiple causes, including patient's attributes, therapeutic process, environmental influences and program characteristics [24-27]. Methadone is highly effective in treating opioid dependence; it is also used as an analgesic for second-line management of chronic pain. Patients enrolled in a methadone maintenance treatment program may become physically dependent and may experience methadone withdrawal symptoms [28]. Opioid overdose was the main cause of the estimated
99,000-253,000 deaths worldwide related to illicit drug use in 2010 [29]. Opioid overdose rates [30] are associated with: an increased availability of opioids, both illicit and prescribed; combination of opioids and other psychoactive substances especially sedating psychoactive substances, (predominantly alcohol and benzodiazepines); a lack of treatment; reduced tolerance due to a recent period of abstinence. Treatment of opioid dependence with opioid agonist maintenance treatment (also known as "opioid substitution treatment") reduces opioid overdose risk by almost 90 per cent [31].

Treatment data provide results on two levels: a direct measurement of the demand on treatment services and an indirect measurement of trends in drug use [32].

Treatment Demand Data (TDI) data are now routinely used in the European Monitoring Centre for Drugs and Drug Addiction (EMCDDA), analyses of the drug situation in Europe, it is widely recognized as the instrument for collecting and reporting data on people entering treatment for their drug use. Drug treatment centers represent a fundamental information source to gain insight into problem drug use, which is difficult to quantify and describe, but not all problem drug users are in contact with treatment, (e.g. some are socially integrated cocaine or cannabis users, some very marginalized heroin users) or they could be in contact with services that, for different reasons, may not collect information from their clients, or do not report it to national monitoring systems. However, in many EU countries the TDI reports information from a considerable number of problem drug users (in some cases over $50 \%$ of the overall estimated number of PDUs). Trends observed in the TDI can signal important developments in problem drug use (e.g. changes in injection behaviour, expansion of use, etc.) and data obtained through the TDI it is an essential component prevalence of problem drug use.

The aim of the survey is to analyze national data from OST medical records and to compare it with the data from EU countries.

\section{Material and Methods}

The survey in this paper is quantitative analytical cross-sectional study conducted in the period September-December 2013. Medical records from all patients on OST at national level during the year 2012 were analyzed. Data was collected with the support of responsible physicians and with respect of confidentiality of the patients. Data for OST patients on MMT was take from all 13 public treatment facilities located in the 10 cities (Skopje, Strumica, Kumanovo, Stip, Ohrid, Gevgelija, Bitola, Veles, Kavadarci and Tetovo), 3 private centers located in the capital of Skopje, and 3 prisons. Data for OST patients on buprenorphine was taken from Clinic for Toxicology, 
Clinical Center "Mother Thereza", University "St. Cyril and Methodius" Skopje.

The data collected for Macedonia was compared with data from 10 EU countries (Austria, Denmark, France, Germany, Greece, Italy, Norway, Portugal, Sweden, UK).

\section{Questionnaire}

For this paper standardized questionnaire, Treatment demand indicator (TDI) - Protocol. 3.0 from EMCDDA [33] were used. The first part of the questionnaire is related to the socio-demographic characteristics as: a) gender, b) age, c) living status (with whom), d) ethnicity, e) drug clients with children, f) living status (where), g) labor status, h) level of education. Second part of the questionnaire was related to poly drug use with focus on benzodiazepines use (secondary drugs).

\section{Statistical analysis}

Descriptive statistics was applied for analyze of data. Excel and Statistics for Windows 7.0 was used. The results were presented in tables.

\section{Results}

\section{Socio-demographic characteristics}

Macedonian legislation set up inclusion criteria for MMT - 18 year of age and above. In special circumstances, younger persons can be included in MMT. In the analyzed period 5 persons were on treatment in the age category 15-19, 1 per MMT in public and private centers and 3 in prisons. With those total No of OST patients are 1,671.

Table 1: OST patients on methadone maintenance treatment.

\begin{tabular}{|c|c|c|c|c|c|c|c|c|c|c|c|c|}
\hline & & \multicolumn{3}{|c|}{$20-34$} & \multicolumn{3}{|c|}{$35-40$} & \multicolumn{3}{|c|}{ 41-55 } & \multirow[t]{2}{*}{ Total } & \multirow[t]{2}{*}{$\%$} \\
\hline & & $\bar{M}$ & $\mathrm{~F}$ & Total & $\mathrm{M}$ & $\mathrm{F}$ & Total & $M$ & $\mathrm{~F}$ & Total & & \\
\hline Public centers & $\begin{array}{l}\text { No } \\
\%\end{array}$ & $\begin{array}{l}510 \\
43.6\end{array}$ & $\begin{array}{l}63 \\
5.4\end{array}$ & $\begin{array}{c}573 \\
49\end{array}$ & $\begin{array}{c}353 \\
30\end{array}$ & $\begin{array}{c}50 \\
4\end{array}$ & $\begin{array}{l}403 \\
34.5\end{array}$ & $\begin{array}{c}176 \\
15\end{array}$ & $\begin{array}{l}17 \\
1.5\end{array}$ & $\begin{array}{r}193 \\
16.5\end{array}$ & $\begin{array}{l}1169 \\
100 \%\end{array}$ & $70 \%$ \\
\hline Private centers & No & $\begin{array}{l}94 \\
67\end{array}$ & 15 & $\begin{array}{c}109 \\
77\end{array}$ & $\begin{array}{l}15 \\
11\end{array}$ & 3 & $\begin{array}{l}18 \\
13\end{array}$ & $\begin{array}{c}11 \\
8\end{array}$ & $\begin{array}{c}2 \\
14\end{array}$ & $\begin{array}{c}13 \\
9\end{array}$ & $\begin{array}{c}140 \\
100 \%\end{array}$ & $8.4 \%$ \\
\hline Prisons & $\begin{array}{l}\text { No } \\
\%\end{array}$ & $\begin{array}{l}207 \\
579\end{array}$ & $\begin{array}{c}12 \\
3\end{array}$ & $\begin{array}{c}219 \\
61\end{array}$ & $\begin{array}{c}116 \\
32\end{array}$ & $\begin{array}{l}0 \\
0\end{array}$ & $\begin{array}{c}116 \\
32\end{array}$ & $\begin{array}{c}22 \\
6\end{array}$ & $\begin{array}{c}1.4 \\
0 \\
0\end{array}$ & $\begin{array}{c}5 \\
22 \\
6\end{array}$ & $\begin{array}{c}357 \\
100 \%\end{array}$ & $22 \%$ \\
\hline TOTAL & $\begin{array}{l}\text { No } \\
\%\end{array}$ & $\begin{array}{c}811 \\
48 \\
\end{array}$ & $\begin{array}{l}90 \\
5.3\end{array}$ & $\begin{array}{c}901 \\
54\end{array}$ & $\begin{array}{c}484 \\
29 \\
\end{array}$ & $\begin{array}{c}53 \\
3 \\
\end{array}$ & $\begin{array}{c}537 \\
32 \\
\end{array}$ & $\begin{array}{c}209 \\
12 \\
\end{array}$ & $\begin{array}{c}19 \\
1 \\
\end{array}$ & $\begin{array}{c}228 \\
14\end{array}$ & $\begin{array}{r}1666 \\
100 \% \\
\end{array}$ & $100 \%$ \\
\hline
\end{tabular}

The total number of patients on methadone therapy (Table 1), refers to 10 cities, where allocated 12 public health centers, with aim residence to have geographically accessible treatment and without financial burden for transport. The number of inhabitants in Republic of Macedonia according to the
State Statistical Office [34], is 2,058,539 inhabitants, distribution of women and men in the total population is equal, $49,9 \%$ of the population are women, $50,1 \%$ are men [35]. From the analyzed data, $0.06 \%$ of the population has developed drug addiction and is included on OST with methadone.

Table 2: Distribution of patients with developed drug addiction, who are receiving OST treatment in decentralized treatment centers in different cities in MKD.

\begin{tabular}{|c|c|c|c|c|c|c|c|c|c|c|c|}
\hline & & Ohrid & Veles & Skopje & Strumica & Bitola & Tetovo & Kavadarci & Gevgelija & Kumanovo & Shtip \\
\hline & TOTAL No & 115 & 46 & 483 & 73 & 92 & 94 & 37 & 61 & 112 & \\
\hline $\begin{array}{l}\text { No of OST } \\
\text { patients }\end{array}$ & $\begin{array}{l}\text { No of } \\
\text { females } \\
\text { (from all } \\
\text { OST } \\
\text { patients) }\end{array}$ & 14 & 6 & 61 & 11 & 7 & 8 & 2 & 8 & 14 & $\begin{array}{c}67 \\
5\end{array}$ \\
\hline $\begin{array}{l}\text { \% of the } \\
\text { population } \\
\text { with } \\
\text { developed } \\
\text { drug } \\
\text { addiction }\end{array}$ & $\%$ & $0.2 \%$ & $0.08 \%$ & $0.1 \%$ & $0.1 \%$ & $0.09 \%$ & $0.1 \%$ & $0.09 \%$ & $0,26 \%$ & $0.1 \%$ & $0.1 \%$ \\
\hline
\end{tabular}

From the data analysis it can be concluded that the number of OST patients is $0.1 \%$ of the total population in each of the 10 cities analyzed, except in Ohrid, where it is $0.2 \%$ and Gevgelija with $0.26 \%$ of the population. Both cities are attractive tourist locations close to the border; the frequency of people is very high, which may be one of the reasons for presence of people with developed opiate addiction, currently in treatment. At the same time it can be concluded that in 10 of 12 cities predominant number of OST patients are with age 20-34 years, except in
Skopje and Ohrid. This information is worrying and it is a clear signal of the need to strengthen preventive measures and activities in MKD.

All OST patients on MMT in prison (Table 1) are from three prisons: pretrial prison "Skopje" were 190 (65\%) OST patients (Total No was 290 prisoners); in prison "Idrizovo" Skopje were $139(11 \%)$ (Total number was 1,306 prisoners) and $38(56 \%)$ in Prison Bitola (total number was 69 prisoners). Other patients (prisoners) within country are receiving MMT from community treatment centers and are presented 
in total number of concerning center. Programs arranged in MKD, transfers community treatment OST patients, in consultation with the patient, on treatment with Methadone while he is in prison, with equal health attention like in community. Those programs also can ensure a smooth transition between prison and the community, after the imprisonment. In MKD there are 3 MMT centers in prisons: in pre-trial prisons in Skopje, prison "Skopje"; in regular prison "Idrizovo" and 38 in Prison Bitola. Other patients (prisoners) within country are receiving MMT from community treatment centers, total number is 60 .Total number of prisoners in OST was 427.

Table 3: Distribution of OST patients on MMT by ethnicity.

\begin{tabular}{lccccc}
\hline Ethnicity & & Public centers & Private centers & Prisons & TOTAL \\
\hline Macedonian & No & 812 & 126 & 180 & 1118 \\
Albanian & $\%$ & 73 & 11 & 16 & $70 \%$ \\
& No & 279 & 7 & 117 & 403 \\
Roma & $\%$ & 69 & 27 & 29 & $24 \%$ \\
& No & 33 & 3 & 60 & 96 \\
Others & $\%$ & 34 & 3 & 63 & $6 \%$ \\
& No & 40 & 5 & 10 & 61 \\
TOTAL & $\%$ & 75 & 8 & 16 & $0.4 \%$ \\
& No & 1164 & 141 & 367 & 1671 \\
& $\%$ & 70 & 8,4 & 22 & $100 \%$ \\
\hline
\end{tabular}

With reflection of the distribution by ethnicity in all treatment facilities with MMT, there are $66.6 \%$ Macedonians, 24\% Albanians, 6\% Roma and 3.6\% Others.

Table 4: Patients on OST treatment with Buprenorphine maintenance in MKD.

\begin{tabular}{|c|c|c|c|c|c|c|c|c|c|c|c|}
\hline \multirow[t]{2}{*}{ Ethnicity } & & \multicolumn{3}{|c|}{$20-34$} & \multicolumn{3}{|c|}{$35-40$} & \multicolumn{3}{|c|}{$41-55$} & \multirow[t]{2}{*}{$\begin{array}{l}\text { TO-TAL } \\
\end{array}$} \\
\hline & & $\mathrm{M}$ & $\mathrm{F}$ & Total & $M$ & $\mathrm{~F}$ & Total & $\mathrm{M}$ & $\mathrm{F}$ & Total & \\
\hline \multirow[t]{2}{*}{ Macedonian } & No & 71 & 17 & 88 & 34 & 0 & 34 & 14 & 0 & 14 & 136 \\
\hline & $\%$ & 52 & 12.5 & 65 & 25 & 0 & 25 & 10 & 0 & 10 & 73 \\
\hline \multirow[t]{2}{*}{ Albanian } & No & 30 & 0 & 30 & 13 & 0 & 13 & 4 & 0 & 4 & \multirow{2}{*}{$\begin{array}{l}47 \\
25\end{array}$} \\
\hline & $\%$ & 64 & 0 & 64 & 28 & 0 & 28 & 8.5 & 0 & 8.5 & \\
\hline Roma & No & 2 & 0 & 2 & 1 & 0 & 1 & 0 & 0 & 0 & 3 \\
\hline \multirow{2}{*}{ TOTAL } & $\%$ & $\begin{array}{l}67 \\
103\end{array}$ & $\begin{array}{c}0 \\
17\end{array}$ & $\begin{array}{l}67 \\
120\end{array}$ & 33 & $\begin{array}{l}0 \\
0\end{array}$ & $\begin{array}{l}33 \\
48\end{array}$ & $\begin{array}{c}0 \\
18\end{array}$ & $\begin{array}{l}0 \\
0 \\
0\end{array}$ & $\begin{array}{c}0 \\
18\end{array}$ & $\begin{array}{l}1.6 \\
186\end{array}$ \\
\hline & $\%$ & 55 & 9 & 65 & 8 & 0 & 26 & 10 & 0 & 10 & $100 \%$ \\
\hline
\end{tabular}

In Macedonia, Buprenorphine is OST which is still exclusively applied in the University Clinic of Toxicology, on the tertiary health care level.

Distribution by ethnicity in treatment facility with Buprenorphine, there are 73\% Macedonians, 25\% Albanians, 2\% Roma.

Total number of OST patients in all available opioid substitution treatment facilities is $1,857,10 \%$ are on Buprenorphine and $90 \%$ are on Methadone, from which 1,355 are in public OST (MMT and
Buprenorphine).

The ratio of male to female heroin clients is $9: 1 ; 162$ are female $(9 \%) ; 10 \%$ are on buprenorphin in comparison with $90 \%$ on methadone; $107(66 \%)$ are in treatment in the age group $20-34 ; 130(80 \%)$ are in public MMT. From all OST patients, 54\% patients on MMT and $65 \%$ OST patients on buprenorphine, are in age category group 20-34. It is evident that very young persons are heroin addicts, already on methadone treatment. It should be noted that injecting heroin in patients currently on drug treatment, starts between 14-22 years of age, and the average age of first heroin use is 18 years.

Analysis of level of education, from the available data, showed that: a) without primary educations are total number of 101 patients $(8.5 \%)$ distributed only in 5 cities (Skopje 49, Shtip 3, Kumanovo 8, Ohrid 17, Tetovo 24) b), with only primary education are 368 patients (32\%); with high school (secondary education) are 683 patients $(59 \%)$ Skopje 337 (29\%), Strumica 47(4\%), Shtip 33(3\%), Bitola 50 (4\%), Kumanovo $51(4 \%)$, Ohrid $46(4 \%)$, Tetovo11 (1\%), Kavadarci 25 (2\%), Veles 41 (3.5\%), Gevgelija 45 (4\%) and with higher education 11(1\%).

Living status data analysis of 1,314 OST patients (except OST patients from 3 prisons): living alone $57(4.3 \%)$; with family $854(65 \%)$; with partner $326(24.8 \%)$; with friends $13(1 \%) ; 4(0.3 \%)$ lives in an institution (not detention); in Prison 60 (4.6\%). 83\% (1090) of the patients have permanent residence. Drug patients with children in public OST: 487 patients $(36 \%)$ have children; living with their children, 337 patients $(69 \%)$; not living with their children, 150 patients $(31 \%)$; no of patients who don't have children, 868 patients $(58.3 \%)$. Labor status of patients on OST in public health institutions: part time job have 188 (14\%); 157 (12\%), permanent employment; $10(1 \%)$ students, not employed are $860(63.4 \%)$, receives of social support, $141(10 \%)$.

Use of benzodiazepines (BZD) as secondary drugs

All public MMT centers recording BZD use, except one MMT center in Skopje and one are collecting medical data for BZD partially. Analyze in public MMT facilities refers to 831 patients, of which 608 use BZD (73\%).

Table 5: Patients on OST treatment with diagnosed BZD use (ICD- 10, F13).

\begin{tabular}{|c|c|c|c|c|c|c|c|c|c|c|c|c|}
\hline & & \multicolumn{3}{|c|}{$20-34$} & \multicolumn{3}{|c|}{$35-40$} & \multicolumn{3}{|c|}{$41-55$} & \multirow[t]{2}{*}{ TOTAL } & \multirow[t]{2}{*}{$\begin{array}{c}\text { Total No OST } \\
\text { patients }\end{array}$} \\
\hline & & $M$ & $F$ & Total & $\mathrm{M}$ & $F$ & Total & $M$ & $\mathrm{~F}$ & Total & & \\
\hline PUBLIC OST & $\begin{array}{l}\text { No } \\
\%\end{array}$ & $\begin{array}{c}289 \\
47\end{array}$ & $\begin{array}{c}22 \\
4\end{array}$ & $\begin{array}{c}311 \\
51\end{array}$ & $\begin{array}{c}205 \\
34\end{array}$ & $\begin{array}{c}13 \\
2\end{array}$ & $\begin{array}{l}218 \\
36\end{array}$ & $\begin{array}{l}72 \\
12\end{array}$ & $\begin{array}{l}7 \\
1\end{array}$ & $\begin{array}{l}79 \\
13\end{array}$ & $\begin{array}{l}608 \\
100\end{array}$ & $\begin{array}{c}831 \\
73\end{array}$ \\
\hline PRIVATE OST & $\begin{array}{l}\text { No } \\
\%\end{array}$ & $\begin{array}{l}76 \\
67\end{array}$ & $\begin{array}{l}11 \\
10\end{array}$ & $\begin{array}{l}87 \\
77\end{array}$ & $\begin{array}{c}13 \\
11.5\end{array}$ & $\begin{array}{l}3 \\
3\end{array}$ & $\begin{array}{l}16 \\
14\end{array}$ & $\begin{array}{l}7 \\
6\end{array}$ & $\begin{array}{c}2 \\
1.7\end{array}$ & $\begin{array}{l}9 \\
8\end{array}$ & $\begin{array}{l}113 \\
100\end{array}$ & $\begin{array}{c}141 \\
80\end{array}$ \\
\hline TOTAL & $\begin{array}{l}\text { No } \\
\%\end{array}$ & $\begin{array}{c}365 \\
51\end{array}$ & $\begin{array}{l}33 \\
4.5\end{array}$ & $\begin{array}{c}398 \\
55\end{array}$ & $\begin{array}{l}218 \\
30\end{array}$ & $\begin{array}{c}16 \\
2\end{array}$ & $\begin{array}{l}234 \\
32.5\end{array}$ & $\begin{array}{l}79 \\
11\end{array}$ & $\begin{array}{l}9 \\
1\end{array}$ & $\begin{array}{l}88 \\
12\end{array}$ & $\begin{array}{c}720 \\
74\end{array}$ & 972 \\
\hline
\end{tabular}


'Analysis determines that: a) there is difference among BZD use and town of living; $b$ ) there is difference in BZD use and distribution by gender and age: $41 \%(398)$ of the patients are in the age group $20-34$; c) there is differences between the gender: Male are predominant with 662 patients $(92 \%)$ in comparison Female are 58 (8\%).
Comparison of Macedonian data with data from 10 EU countries (Austria, Denmark, France, Germany, Greece, Italy, Norway, Portugal, Sweden, UK

In EU 4:1 is the ratio of male to female heroin clients [36]. In Macedonia (MKD) the ratio of male to female heroin clients is 9:1.

Table 6: Distribution of patients with diagnosed BZD use, who are receiving OST treatment in decentralized treatment centers in different cities in MKD.

\begin{tabular}{|c|c|c|c|c|c|c|c|c|c|c|}
\hline $\begin{array}{l}\text { No of patients using BZD } \\
\text { Total No of OST patients }\end{array}$ & $\begin{array}{l}\text { No } \\
\% \\
\text { No }\end{array}$ & $\begin{array}{c}\text { Ohrid } \\
107 \\
93 \% \\
115 \\
\end{array}$ & $\begin{array}{c}\text { Veles } \\
42 \\
91 \% \\
46 \\
\end{array}$ & $\begin{array}{c}\text { Skopje } \\
163 \\
81 \% \\
201 \\
\end{array}$ & $\begin{array}{c}\text { Strumica } \\
58 \\
79 \% \\
73\end{array}$ & $\begin{array}{c}\text { Bitola } \\
59 \\
64 \% \\
92 \\
\end{array}$ & $\begin{array}{c}\text { Tetovo } \\
54 \\
69 \% \\
94 \\
\end{array}$ & $\begin{array}{c}\text { Kavadarci } \\
19 \\
56 \% \\
37 \\
\end{array}$ & $\begin{array}{c}\text { Gevgelija } \\
34 \\
56 \% \\
61\end{array}$ & $\begin{array}{c}\text { Kumanovo } \\
61 \\
53 \% \\
53\end{array}$ \\
\hline
\end{tabular}

Study in Israel has shown that females are more likely to enter MMT at a younger age than males, with more than double percentage of total female admissions occurring in the 18-30 age groups [37]. It is the similar situation in MKD where $1.6 \%$ of female patients are in treatment in the age group 2034. In Macedonia male patients are $89 \%$ from all patients, while in analysis carried out in ten EU countries (with The European Quality Audit of Opioid Treatment (EQUATOR [38], designed to provide an overview of the current state of opioid treatment provision in Europe) found $74.6 \%$ male patients. This distribution was also seen in individual countries and consistently are more men patients (range 66-82\%) [39], 79\% male opioid-dependent patients observed by the EMCDDA (data from countries taking part in EQUATOR) [40], $84 \%$ of OST patients in the PROTEUS study in Spain [41], $73 \%$ of OST in the DTORS study in the UK [42] and $68 \%$ male patients in the German PREMOS study [43]. The average age of patients across Europe was 36.5 years, ranging from an average of 31.9 years in Austria to 43.8 years in Denmark [44]. In the same way, the mean age of patients entering treatment for opioid dependence in the EMCDDA dataset [45] was 34.1 years; the mean age reported in the German COBRA [46] study 34.8 years and in the PREMOS [47] study 35 years; PROTEUS [48] study in Spain, reported mean age 39 years. In the UK DTORS study [49], patient on OST were aged between 25 and 44 years $(45 \%$ were 25 34 years; $27 \%$ were $35-44$ years, $7 \%$ were $\geq 45$ years). Among Macedonian OST patient treated in public health facilities in 2012, data for age distribution is similar with findings of UK study with $52 \%$ patients in age category group $20-34 ; 33 \%$ in age group $41-55$; and $16 \%$ between $41-55$ years, which is evident that very young persons are heroin addicts already on methadone treatment.

It should be noted that injecting heroin in patients currently on treatment of drug addiction in 2012, in the Republic of Macedonia is between 14-22 years of age. The mean age at first heroin use in EU [50] is 22 years and in comparison, in Macedonia is 18 years.

\section{Discussions}

Treatment network of drug addiction in MKD is quite developed. However, it is necessary to further build the capacities and to increase the quality of medical care that will increase the availability, accessibility, diversification in terms of sensitivity to cultural differences, gender, age, ethnicity, as well as possibilities of treatment of different types of psychoactive substances not only heroin users but also cocaine, marijuana and users of new psychoactive substances, synthetic drugs etc.

Methadone was introduced in MKD in 1992 for opioids substitution treatment OST (MMT). Buprenorphine, introduced in 2009, is used for detoxification and substitution treatment. Nearly 1,250 drug users are involved in a program for methadone maintenance therapy and receive daily or weekly substance. Government of the Republic of Macedonia adopts the program each year for health care (covering all expenses for OST) for people with diseases of addiction. In the framework of the program for Building a Coordinative Response to HIV/AIDS Prevention in the country (supported by the Global Fund), the Ministry of Health opened 12 services for treatment and harm reduction of drug abuse, with methadone maintenance treatment, in 10 cities in MKD, as well as 3 programs in the prisons. A barrier to treatment entry like waiting lists for patients on methadone substitution program is not an issue in MKD. But, apparent problem is accumulation of big number of patients per centre especially in the city of Skopje. This could be overcome with expand of treatment access in different municipalities within the capital city Skopje, which besides the improvement in quality of health care, will be of benefit for the patients to reduce transport costs. In MKD, General population survey (GPS) is not performed yet, due to the lack of financial resources. Most recent scientific estimates which derived from the multiplier methods (RDS study) and Delphi estimate, suggests that the average number of Injecting drug users (IDUs) in Skopje is 2,950 [51]. This study indicated that if the IDUs 
number in Skopje is 2,950, than the extrapolation of this estimate to the national level will give the total estimated number of 10,200 IDUs $(95 \% \mathrm{Cl}=7450-$ 14150; rounded to nearest fifty) in Macedonia. However, extrapolation of results from Skopje to other smaller cities in MKD and methodology for this studies should be taken with caution because it have run into divided expert opinions, especially the experts from EU countries (key experts within the REITOX network of the EMCDDA, for the Indicator problematic drug users (PDUs).

Gender is an important variable to consider in substance abuse treatment research. Female substance abusers experience a number of barriers to receiving treatment, including child care responsibilities, stigmatization, and religion obstacles. Female substance abusers are more vulnerable than male to some of the physiological effects of substance, also substance abuse among females is rooted more often in psychosocial problems and traumatic life events and these important gender differences suggest the need for specialized treatment programming for women [52].

With regards to level of education, comparison between MKD data and data presented in studies, showed that MKD patients in OST with 37\% of patients, with no high school is near data from Sweden (35.5\%) and UK (39.5), lower than EU average (42.3), Denmark (56.3\%), Germany (59\%), Italy (54\%). With $62 \%$ of high school education degree among MKD patients in OST is equal with findings in Spain (62.4\%); higher than EU average (30.9\%). With $1 \%$ of Graduate education, MKD is identical with UK $(1.2 \%)$, which is bigger than EU average $(0.3 \%)$.

Demographic data are important for understanding the real-life circumstances and potential clinical needs of the target population for OST, because the new focus on 'recovery' places great emphasis on helping patients not only to reduce their drug use but also to build and exploit their own social, physical, financial and cultural resources to sustain their recovery and reintegrate into society [53]. It is therefore useful to understand the educational, marital, employment status and other demographic characteristics of those who are in or out of treatment in order to assess their ability to achieve these goals [54].

It has been estimated that up to one third of all heroin dependent people pass through a correctional facility each year [55]. The chronic nature of untreated heroin dependence means that imprisonment is usually a repeated experience; in studies in the US and France, half of heroin users released from prison were returnees in prison within six months [56-57].

Polydrug use is predominant among drug users mixing of substances is carried out to reduce the unwanted effects or to enhance the desired ones
[58-61]. The substances detected most often were combinations of morphine, benzodiazepine, methadone, stimulants. In terms of poly drug use, the use of benzodiazepines ranges between $11 \%$ and 70 $\%$ among substitution treatment clients [62]. Benzodiazepines are widely used by heroin dependent individuals and by patients in opioid substitution treatment [63]. This high level of use may be in response to the high incidence of psychiatric comorbidity in this population [64].

Benzodiazepine use by MMT patients is associated with a more complex clinical picture and may negatively influence treatment outcomes [65]. Although several studies indicate that rates of nonmedical prescription drug use are higher among women than men, particularly for narcotic analgesics and tranquilizers [66], other studies report equivalent or higher rates among men [67].

In this moment it is difficult to recognize single medical opiate users, but in very near future with implementation of electronic health card, with recording of health status for single patient it will be very easy to obtain health statistics, for scientific purposes and with respect of personal's confidential information. For the purpose of this paper we can look through data for use of opiates and opioids for medical purposes, expressed as grams of active component controlled by Conventions for drug control of the United Nations (UN 1961, 1971, 1988). MKD is a country that cultivate poppy (Papaver somniferum) and performs extraction of alkaloids for medical purposes, i.e. providing primary production of opiates (natural derivatives of opium). In terms of synthetic opioids MKD performs secondary production. From produced amounts of opiates and opioids parts are exported to other countries and part is for domestic medical purposes. The whole process is approved by the MKD Ministry of Health and International Board for Drug Control of the United Nations. Approved MKD data for opiates are part of INCB annual reports [68]. Annual estimated needs [69] for substitution treatment in MKD for drug addiction is $38 \mathrm{~kg}$ of $400 \mathrm{~g}$ methadone for 1200 patients and buprenorfin for 210 patients $1 \mathrm{~kg}$ $95 \mathrm{~g}$.

Concerning medical opiates, data from Form C report for 2012 [70] are: from the produced $1,343 \mathrm{~kg}$ and $249 \mathrm{~g}$ Codeine, only $30 \mathrm{~g}$ were consumed like Codeine, other quantities were utilized for the manufacture of Schedule III preparations; from the produced $5 \mathrm{~kg}$ and $614 \mathrm{~g}$ Morphine Hydrochloride and Sulphat, only $30 \mathrm{~g}$ were consumed in MKD, other quantities were exported for medical purposes; $87 \mathrm{~kg}$ and $302 \mathrm{~g}$ of Pholcodine were utilized for manufacture of Schedule III preparations. With regards to opioids MKD patients in 2012 consumed $17 \mathrm{mg}$ Fentanyl and $7 \mathrm{mg}$ Remifentanyl. From produced $180 \mathrm{~kg}$ Methadone, only $25 \mathrm{~kg}$ were used in MKD, other quantities were exported with approval from Macedonian Ministry of Health and UN INCB, to other 
countries, for medical purposes.

In Macedonia different treatment options for opioid dependent persons are functioning. Persons in prisons receive the same level of health care like in the community. Demographic profiles appeared relatively consistent across the country, with differences in mean age of patients in treatment, namely while in capital city Skopje predominant age group is 35-40, in rest of Macedonian towns patients are on the age $20-34$. It should be noted that in private OST psychiatric clinics, no meter that all are placed in capital city Skopje, patients are with age 20-34. The same situation is among prison patients, $62 \%$ are on the age 20-34. It is important to strengthen drugs preventive measures, to raise awareness and level of information. Ratio female: male patients is bigger that EU average and it should be further explored what are the reasons. There is correlation between low level of education and start of heroin abuse. Benzodiazepine use among MMT patients is common. This very important and comprehensive analyze of persons with drug addiction can lead to successful prevention and treatment responses. Although treatment network of drug addiction is quite developed, perceived need for further capacity building and increase the quality of medical care implies increasing the availability, diversification in terms of sensitivity to cultural differences, gender, age, ethnicity, as well as the treatment of dependence of different types of psychoactive substances.

\section{References}

1. UNODC: The Global Afghan Opium Trade, A Threat Assessment, 2011.

2. Dimovski Z, Babanoski K, llijevski I. Republic of Macedonia as a Transit Country for the Illegal Trafficking in the "Balkan Route". Varstvoslovje, Journal of Criminal Justice and Security, 2012;15(2): 203-217.

3. http://www.emcdda.europa.eu/themes/key-indicators/pdu

4. Perspectives on drugs, Trends in heroin use in Europe: what do treatment demand data tell us? Emcdda, updated 28. 5. 2013, http.//www.emcdda.europa.eu/topics/ pods/trends-inheroin-use

5. Effectiveness of drug dependence treatment in preventing HIV among injecting drug users. Geneva: World Health Organization, http://www.who.int/hiv/pub/idu/en/drugdependencefinaldraft.pdf 2005

6. National Institutes of Health National Institute on Drug Abuse. July7, 2011 http://www.drugabuse.gov/ScienceofAddiction/addiction.html.

7. Robinson TE, Berridge KC. Brain Res Rev.1993;18(3):247291.

8. O'Brien CP, McLellan AT. Lancet. 1996;347(8996):237-240.

9. McLellan AT et al. JAMA. 2000;284(13):1689-1695.

10. Weber $\mathrm{R}$ et. al. Uptake of and virological response to antiretroviral therapy among HIV-infected former and current injecting drug users and persons in an opiate substitution treatment programme: the Swiss HIV Cohort Study. HIV Medicine. 2009;10(7):407-416.
11. World Drug Report 2012 - United Nations Office on Drugs and Crime http://www.unodc.org/doc/wdr/Chp1_A.pdf

12. Michelle Kermode, Nick Crofts, M Suresh Kumar \& Jimmy Dorabjee Opioid substitution therapy in resource-poor settings. Bulletin of the World Health Organization. 2011;89:243-243.

13. Lawrinson $P$, Ali $R$, Buavirat $A$, Chiamwongpaet $S$, Dvoryak $S$, Habrat B, et al., et al. Key findings from the WHO collaborative study on substitution therapy for opioid dependence and HIV/AIDS. Addiction. 2008; 103: 1484-92.

14. Gowing $L$, Farrell $M$, Bornemann $R$, Sullivan LE, Ali $R$. Substitution treatment of injecting opioid users for prevention of HIV infection. Cochrane Database Syst Rev. 2008; 2: CD004145-.

15. Weber R, Huber M, Rickenbach M, Furrer H, Elzi L, Hirschel $\mathrm{B}$, et al., et al. Uptake and virological response to antiretroviral therapy among HIV infected former and current injecting drug users and persons in an opiate substitution treatment program: the Swiss HIV Cohort Study. HIV Med. 2009; 10: 407-16.

16. R. Kathryn McHugh, Bridget A. Hearon, and Michael W. Otto. Cognitive-Behavioral Therapy for Substance Use Disorders Psychiatr Clin North Am. 2010; 33(3): 511-525.

17. Connock M, Juarez-Garcia A, Jowett S, Frew E, Liu Z, et al. Methadone and buprenorphine for the management of opioid dependence: a systematic review and economic evaluation. Health Technol Assess. 2007; 11: 1-171, iii-iv.

18. Joseph $H$, Stancliff $S$, Langrod J.Methadone maintenance treatment (MMT): a review of historical and clinical issues. Mt Sinai J Med. 2000;67(5-6):347-64.

19. Lawrinson $\mathrm{P}$, Ali R, Buavirat A, Chiamwongpaet S, Dvoryak S, et al. Key findings from the WHO collaborative study on substitution therapy for opioid dependence and HIV/AIDS. Addiction. 2008;103: 1484-1492.

20. Gruber SA, Tzilos GK, Silveri MM, Pollack M, Renshaw PF, Kaufman MJ, Yurgelun-Todd. Methadone maintenance improves cognitive performance after two months of treatment. Clin Psychopharmacol. 2006; 14(2):157-64.

21. De Maeyer J, Vanderplasschen W, Camfield L, Vanheule S, Sabbe B, Broekaert E.A good quality of life under the influence of methadone: a qualitative study among opiate-dependent individuals. Int J Nurs Stud. 2011;48(10):1244-57.

22. Effectiveness of drug dependence treatment in preventing HIV among injecting drug users. Geneva: World Health Organization; 2005. Available from: http://www.who.int/hiv/pub/idu/en/drugdependencefinaldraft.pdf

23. Raffa JD, Grebely J, Tossonian H, Wong T, Viljoen M, et al. The impact of ongoing illicit drug use on methadone adherence in illicit drug users receiving treatment for HIV in a directly observed therapy program. Drug Alcohol Depend. 2007; 89: 306-309.

24. Nosyk B, Marsh DC, Sun H, Schechter MT, Anis AH. Trends in methadone maintenance treatment participation, retention, and compliance to dosing guidelines in British Columbia, Canada: 1996-2006. J Subst Abuse Treat. 2010; 39: 22-31.

25. Liu E, Liang $T$, Shen L, Zhong $\mathrm{H}$, Wang B, et al. Correlates of methadone client retention: a prospective cohort study in Guizhou province, China. Int J Drug Policy. 2009; 20: 304308.

26. Banta-Green CJ, Maynard C, Koepsell TD, Wells EA, Donovan DM. Retention in methadone maintenance drug treatment for prescription-type opioid primary users compared to heroin users. Addiction. 2009; 104: 775-783.

27. Soyka M, Zingg C, Koller G, Kuefner H. Retention rate and substance use in methadone and buprenorphine maintenance therapy and predictors of outcome: results from a randomized study. Int J Neuropsychopharmacol. 2008; 11: 641-653.

28. Reingardiene D, Jodziūniene L, Lazauskas R. Methadone 
treatment and its dangers. Medicina (Kaunas). 2009; 45(5):419-25.

29. World Drug Report 2012 (United Nations publication, Sales No. E.12.XI.I), p.11.

30. Discussion paper UNODC/WHO 2013. Opioid overdose: preventing and reducing, opioid overdose mortality Contribution of the United Nations Office on Drugs and Crime and the World Health Organization to improving responses by Member States to the increasing problem of opioid overdose deaths. UN, New York, 2013.

31. World Health Organization, Guidelines for the Psychosocially Assisted Pharmacological Treatment of Opioid Dependence (Geneva, 2009)

32. Stauffacher M. Drug treatment data as an epidemiological indicator indicator: methodological considerations Bulletin on Narcotics, United Nations Journal. The science of drug abuse epidemiology. 2002; (vol. LIV, No.1 and 2)

33. Montanari L et al. Treatment demand indicator (TDI) Standard Protocol 3.0.Guedlines for reporting data on people entering drug treatment in European countries. EMCDDA. 2012.

34. Population estimates, 31.12.2011, by sex, age and statistical regions. State Statistical Office of the Republic of Macedonia, 2012.

35. Women and men in the Republic of Macedonia, 2012 Republic of Macedonia, State Statistical Office Publisher: The State Statistical Office, Skopje, Dame Gruev 4, 2012.

36. EMCDDA Perspectives on drugs, Trends in heroin use, in Europe includes the $27 \mathrm{EU}$ Member States, Croatia, Turkey and Norway, 2013.

37. Schiff M, Levit S, Moreno RC. Retention and illicit drug use among methadone patients in Israel: a gender comparison. Addictive Behaviors. 2007;32:2108-2119.

38. Fischer G., Stöver H. Assessing the current state of opioiddependence treatment across Europe: methodology of the European Quality Audit of Opioid Treatment (EQUATOR) project. Heroin Addict Relat Clin Probl. 2012; 14: 5-70.

39. Goulão J, Stöver H. The profile of patients, out-of-treatment users and treating physicians involved in opioid maintenance treatment in Europe. Heroin Addict Relat Clin Probl. 2012; 14(4): 7-22.

40. EMCDDA: Statistical bulletin

2012 www.emcdda.europa.eu//stats $12 /$ list

41. Roncero C. on behalf of the PROTEUS Study investigators: Therapeutic management and comorbidities in opiatedependent patients undergoing a replacement therapy programme in Spain: the PROTEUS study. Heroin Addict Relat Clin Probl. 2011; 13: 5-16.

42. Jones A, Weston S, Moody A, Millar T, Dollin L, Anderson T, Donmall M. The Drug Treatment Outcomes Research Study (DTORS): Research Report 3. 2007. www.dtors.org.uk

43. Wittchen HU, Bühringer G, Rehm J. Ergebnisse und Schlussfolgerungen der Premos-Studie (Predictors, Moderators and Outcome of Substitution Treatment). Suchtmedizin in Forschung und Praxis. 2011; 13: 199-299.

44. Goulão J, Heino Stöver.The profile of patients, out-oftreatment users and treating physicians involved in opioid maintenance treatment in Europe. Heroin Addict Relat Clin Probl 2012; 14(4): 7-22

45. www.emcdda.europa.eu

46. Wittchen $\mathrm{HU}$ et al. Feasibility and outcome of substitution treatment of heroin-dependent patients in specialized substitution centers and primary care facilities in Germany: a naturalistic study in 2694 patients. Drug Alcohol Depend. 2008; 95: 245-257.
47. Wittchen HU et al. Ergebnisse und Schlussfolgerungen der PREMOS-Studie (Predictors, Moderators and Outcome of Substitution Treatment). Suchtmedizin in Forschung und Praxis. 2011; 13: 199-299.

48. Roncero $\mathrm{C}$, on behalf of the PROTEUS study investigators. Therapeutic management and comorbidities in opiatedependent patients undergoing a replacement therapy programme in Spain: the PROTEUS study. Heroin Addict Relat Clin Probl. 2011; 13: 5-16.

49. Jones A, et al. The Drug Treatment Outcomes Research Study (DTORS): baseline report. Research Report 3. 2007. www.dtors.org.uk.

50. Cloud W, Granfield R. Conceptualizing recovery capital: expansion of a theoretical construct. Subst Use Misuse. 2008; 43: 1971-1986.

51. Kuzmanovska G. Mikik V. Stojanovik S. Report from the assessment of population size of injecting drug users in Kumanovo, Gostivar, Strumica, Ohrid and Skopje,Institute of Public Health, Department for Control and Prevention of Communicable Diseases and Joint Un program on HIV/AIDS Skopje, 2010.

52. Goulão J, Stöver H. The profile of patients, out-of-treatment users and treating physicians involved in opioid maintenance treatment in Europe. Heroin Addict Relat Clin Probl. 2012; 14(4): 7-22

53. Brady TM, Ashle OS. Women in Substance Abuse Treatment: Results from the Alcohol and Drug Services Study (ADSS) Department of Health and human services. Substance Abuse and Mental Health Services Administration Office of Applied Studies, September 2005. http://www.oas.samhsa.gov

54. Boutwell $A E$, et al. Arrested on heroin: A national opportunity. Journal of Opioid Management. 2007; 3:328-32.

55. Marzo JN, et al. Maintenance therapy and 3-year outcome of opioid dependent prisoners: A prospective study in France (2003-2006).Addiction. 2009;104:1233-40.

56. McMillan GP, Lapham S, Lackey M. The effect of a jai methadone maintenance therapy (MMT) program on inmate recidivism. Addiction. 2008; 103:2017-23.

57. Hunt G, Evans K, Moloney M, Bailey N. Combining different substances in the dance scene: enhancing pleasure, managing risk and timing effects. J Drug Issues. 2009; 39: 495-522.

58. Lankenau SE, Clatts MC. Patterns of Polydrug Use among Ketamine Injectors in New York City. Subs Use Misuse. 2005; 40: 1381-1397

59. Klein H, Elifson KW, Sterk CE. Young adult Ecstasy user's enhancement of the effects of their ecstasy use. J Psychoactive Drugs. 2009; 41: 113-120.

60. Fischer $\mathrm{G}$ et al. The non-medical use of prescription drugs Policy direction issues, United Nations Office on Drugs and crime, New York, 2011.

61. Lintzeris $\mathrm{N}$ et al. Pharmacodynamics of diazepam coadministered with methadone or buprenorphine under high dose conditions in opioid dependent patients. Drug and Alcohol Dependence. 2007; 91: 187-194.

62. Kandel D, Huang FY, Davies M. Comorbidity between patterns of substance use dependence and psychiatric syndromes. Drug Alcohol Depend. 2001; 64: 233-241.

63. Brands B, Blake J, Marsh DC, Sproule B, Jeyapalan R, Li S. The impact of benzodiazepine use on methadone maintenance treatment outcomes. J Addict Dis. 2008;27(3):3748.

64. Simoni-Wastila L, Ritter G, Strickler G. Gender and other factors associated with the nonmedical use of abusable prescription drugs. Subst Use Misuse. 2004;39(1):1-23. 
65. Blanco C, Alderson D, Ogburn E, et al. Changes in the prevalence of non-medical prescription drug use and drug use disorders in the United States. Drug Alcohol Depend. 2007;90(2-3):252-60.

66. Gaulier JM, Marquet P, Lacassie E, Dupuy JL, Lachatre G. Fatal intoxication following self-administration of a massive dose of buprenorphine. Journal of Forensic Sciences. 2000;45(1):226-228.

67. http://www.incb.org/incb/en/narcoticdrugs/Technical_Reports/narcotic_drugs_reports.html

68. http://www.incb.org/incb/en/narcoticdrugs/Technical_Reports/narcotic_drugs_reports.html

69. Health care program for people with addictions in RM 2012 Official Gazette no. 8 , 2012.

70. Form C 2012 for The Republic of Macedonia. INCB, Annual Statistics of production, manufacture, consumption, stocks and seizures of Narcotic drugs, Single Convention on Narcotic Drugs of 1961: articles 1, 2, 13, 20 and 27, 1972. Protocol amending the Single Convention on Narcotic Drugs of 1961 articles 1 and 10. Ministry of Health of the Republic of Macedonia, 2012. 